Historic, Archive Document

Do not assume content reflects current scientific knowledge, policies, or practices. 


\subsection{9}

1908

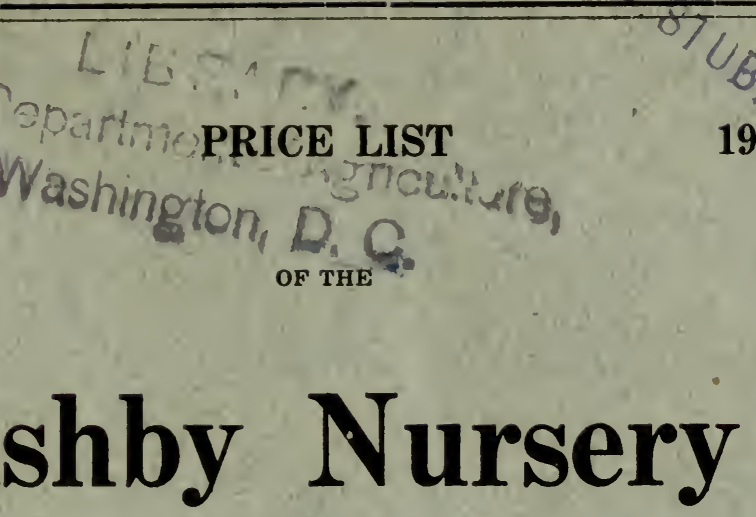

\section{Ashby Nursery}

FRUIT TREES, ORNAMENTAL TREES, SHRUBS, ROSES, PALMS, BEDDING AND BORDER PLANTS, BULBS, VINES, HOUSE PLANTS, SEEDS.

W. H. WOLTERS, Proprietor.

A Cordial Invitation is Extended to visit and inspect our Nursery, at

\section{ELLSWORTH STREET}

$$
\text { Near Russell, one block west of }
$$

Telegraph Ave. 


\section{To My Patrons:}

I bég to offer you my price-list for the year 1909 .

At the time this list is issued, my stock is in exceptionally good condition, having been mostly grown on my own grounds.

Your generous patronage during the last year is appreciated, and I shall endeavor to merit a continuance of the same.

W. H. WOLTERS.

Make your yard your own door parlor,

Plant the rose and vine on arbor;

Choose from me the very best,

Call or.write or 'phone-the rest

We'll attend to without fail

And forward promptly through the mail

Or by express, if large the sale.

\section{TERMS OF SÁLE}

Prices herein quoted are for cash. In ordering, please give explicit directions for forwarding. My responsibility ends upon safe delivery to railroad or express company.

Local Delivery. - We deliver goods free in Oakland, Berkeley, Alameda and Fruitvale.

In ordering please state whether substitution will be permitted, if goods ordered are exhausted.

Write to us for special prices on large lots.

All orders are filled promptly.

Our customers are requested to notify us immediately of any errors that may be committed in filling their orders, so that we may at once rectify the same, as we desire to conduct our business in all respects satisfactorily to those who favor us with their confidence.

If any plants or seeds not mentioned in this price list are desired, write to us and we will endeavor to secure them for you. Orders for propagation in large quantities will be filled if desired.

Address all communications to

ASHBY NURSERY, 2906 Ellsworth St.

Phone Berkeley 1476 S. Berkeley, Cal. 


\section{PRICE LIST}

\section{OF THE \\ ASHBY NURSERY.}

\section{FRUIT TREES AND SMALL FRUITS.}

\section{APPLES_Summer.}

25 c each; size, 4 to 6 feet high.

Gravenstein.-A large, striped, beautiful, roundish apple, of first quality; juicy, high flavored; a good grower and prolific bearer.

Red Astrachan.-Large, roundish, nearly covered with a deep crimson; very handsome, juicy, good, though rather acid; an early and abundant bearer; the best early apple.

Red June.-Medium; deep red; good; very productive; early bearer.

William Favorite.-An early bearer; large yellow.

\section{APPLES-Autumn.}

$25 \mathrm{c}$ each; size, 4 to 6 feet high.

Alexander.-A very large, deep red or crimson apple of medium quality; hardy and fairly productive; an excellent market sort.

Jonathan.-Medium to large, striped, mostly red; tender, juicy, rich vinous flavor; very productive, and one of the best varieties either for table or market.

Rhode Island Greening.-A great and constant bearer in almost all localities; fruit large, greenish yellow.

Yellow Pippin.-Very large; an elegant apple for shipping.

\section{APPLES-Winter.}

$25 \mathrm{c}$ each; size, 4 to 6 feet high.

Northern Spy.-Large, roundish, prettily striped with red and delicately coated with bloom; mild, pleasant flavor; rapid and erect grower.

Spitzenberg.-Large oblong yellow, with broken stripes of bright red.

Yellow Bellflower.-A large, handsome and excellent winter apple; skin smooth, pale lemon yellow, often with a blush next the sun; flesh tender, juicy, crisp, with a sprightly sub-acid flavor; one of the very best.

Yellow Newton Pippin.-Large, yellow, firm, crisp, juicy, with a very rich, high flavor; the best winter apple.

\section{PEARS.}

$30 \mathrm{c}$ each; 4 to 6 feet high.

Bartlett.-One of the most popular pears; the best early pear, and has no competitor as a market and canning fruit. 


\title{
CHERRIES.
}

\author{
$40 \mathrm{c}$ each; 4 to 6 feet high.
}

Black Tartarian.-Fruit of the largest size; bright purplish black; flesh purplish, thick, juicy, very rich and delicious; tree a remarkably vigorous, erect and beautiful grower and an immense bearer; the best of the black eherries.

Centennial.-A seedling of Napoleon Bigarreau. It is larger than its parent, and beantifully marbled and splashed with crimson on a pale yellow ground; its keeping qualities render it the best cherry for shipment.

Royal Ann.-A large white eherry with rosy eheeks; best for preserving.

\section{PEACHES-Freestone Varieties.}

\author{
$40 \mathrm{c}$ each; 4 to 6 feet high.
}

Alexander.-The best very early freestone; medium to large size; greenish white, nearly covered with a deep, rich red; very juicy, sweet and of good quality.

Early Crawford.-A magnificent, large, yellow peach, of good quality; its size, beauty and productiveness make it one of the most popular varieties.

Salway.-A large, yellow, English peach, with deep yellow flesh; very juicy, melting and rich; the most valuable late market variety.

\section{PEACHES-Clingstone Varieties.}

\author{
$40 \mathrm{c}$ each; 4 to 6 feet high.
}

Cling Muir.-The best peach for canning and drying.

Orange.-Superior to the common Orange Cling, and is not subject to mildew like that variety; fruit very large; skin yellow, with a dark crimson cheek; flesh yellow, rich and sugary, with a decided vinous flavor.

\section{PLUMS.}

$30 \mathrm{c}$ each; 4 to 6 feet high.

Burbank.-Tree vigorous grower, with strong, upright shoots; large, broar leaves; bears early; fruit very large, rich, cherry red, slightly mottled with yellow; flesh deep yellow, juicy, very sweet; agreeable flavor. August.

Green Gage.-Small, but of the highest excellence; round, greenish yellow, with brown dots; very juicy and sweet.

Yellow Egg.-A very large and beautiful, egg-shaped, yellow plum; flesh yellow, rather acid until very ripe, when it becomes sweet.

\section{PRUNES.}

\author{
$30 \mathrm{c}$ each; 4 to 6 feet high.
}

French (Petite d'Agen, Burgundy Prune).-The well known variety so extensively planted for drying; medium size, egg-shaped, violet purple; juicy, very sweet, rich and sugary.

German (Common Quetsche).--Long, oval and swollen on one side; skin purple, with a thick blue bloom; flesh firm, green, sweet, with a peculiar, pleasant flavor; separates readily from the stone. September. 
APRICOTS.

35 c each; 4 to 6 feet high.

Hemskirke.-Strongly resembles the Moorpark in size and colol but differs from that variety in ripening a little earlier and more exoly. July to August.

Moorpark.-One of the largest, most popular and widely difseminated apricots; deep orange or brownish red; flesh quite firm, bright opange, parting freely from the stone; quite juiey, with a rich and daclous flavor; a favorite eanning variety. August.

Royal. - A standard variety; skin dull yellow, wît an orange cheek; flesh pale orange, firm and juicy, with a rich, vinousflavor. July.

\section{QUINCES.}

40e each; 4 to 5 feet high.

Apple or Orange.-Large, roundish, with short neck; fruit a beautiful bright golden yellow color; an old favorite sort. September.

\section{ORANGES.}

Washington Navel.-Price, 5 to 6 feet, $\$ 2.50$ each.

\section{LEMONS.}

Eureka.-The best variety, perfectly hardy. Price, 4 to 5 feet, $\$ 2.00$ each.

\section{ALMONDS.}

$35 \mathrm{c}$ each; 4 to 6 feet high.

Paper Shell.-Medium size; shell very tender, easily broken hetween the finger and thumb; kernel large, white, sweet and relishing.

\section{FIGS.}

35c each; 3 to 4 feet high.

California Black.-The well-known local variety; fruit large, dark purple, almost black when fully ripe; makes a good dried fig; tree grows to a very large size and bears immense crops.

White Genoa.-Fruit very large; flesh brownish purple, rich and fine grained; skin light green; it produces large crops during the entire season until October.

\section{WALNUTS.}

60e each; 4 feet high.

Santa Barbara Soft Shell.-A variety originating with Joseph Sexton, of Santa Barbara, Cal. The tree is a vigorous grower, an early and abundant 
bearer; the nut is large, the kernel white, sweet and readily extracted, the shell being easily broken.

\title{
GRAPES.
}

\author{
Strong roots; $15 \mathrm{c}$ each.
}

Black Hamburg.-A fine, tender grape, producing large, magnificent, compact bunches; berries black, very large and oblong; a great favorite everywhere.

Thompson's Seedless.-A seedless variety, resembling the Sultana in some respects, but in others much superior; extensively grown in sutter county, and locally known by this name. In the vineyard of .J. B. (Instott, of Yuba City, the vine is exceedingly prolific, and the fruit very fine.

\section{CURRANTS.}

15c each; strong 2-year-old.

Black Naples.-A beautiful fruit, the finest and largest of all black currants; highly esteemed for jelly.

Cherry.-Fruit of the largest size; bunches short; berries large, deep red; a valuable market sort.

\section{GOOSEBERRIES.}

$20 \mathrm{c}$ each.

Berkeley (Dwinelle, Kelsey, New French).--Under all these names this variety has been introduced here; it has been sufficiently tried to determine its qualities and characteristics; it is immensely prolific, large and handsome.

Champion.-A variety introduced here from Oregon, where it originated; fruit large, round; an immense bearer, and entirely free from nildew.

\section{BLACKBERRIES.}

$15 \mathrm{e}$ each; $\$ 1.50$ per dozen.

Himalaya Giant.-Introduced here from Oregon; origin unknown; beautiful, cut-leaved foliage, which it retains during the winter; berries large, black, sweet, rich and delicious; it continues to ripen from August to November, which makes it one of the best berries for family use; an excellent trellis and arbor plant.

Lawton.-Fruit large; ripens late; very productive.

Mammont.-A heavy bearer; large, sweet berries; very early.

Texas Everbearing.-A productive berry, bearing from early spring to late fall.

\section{LOGAN BERRIES.}

10e each; $\$ 1.00$ per dozen.

Vine an exceedingly strong grower; trails upon the ground like a dewberry; fruit is often an inch and a quarter long, dark red, with the shape of a blackberry, the color of a raspberry, and a combination of the flavors of both; a great acquisition to the berries on the market; a splendid shipper. 


\section{RASPBERRIES.}

5e each; 50c per dozen.

Cuthbert (Queen of the Market).-The largest, handsomest anil best red raspberry eultivated; bears transportation well; very productive.

\section{STRAWBERRIES.}

25e per dozen.

Brandywine.-Plant, a luxuriant grower, healthy and hardy, and very productive; hlossom perfect; fruit very large, of good form, bright red all over, and of good quality.

\section{ASPARAGUS.}

5e each; 50e per dozen.

Conover's Colossal.- The standard variety; large and productive; almost un1versally cultivated in this state.

\section{HORSERADISH.}

$10 \mathrm{c}$; strong roots.

\section{RHUBARB, OR PIE PLANT.}

15c each for strong roots.

Limnaeus.-Large, early, tender and fine; the very best of all.

\section{DECIDUOUS TREES AND SHRUBS.}

Acer Macrophyllum (Large-leaved Maple).-A most graceful tree, with wirlespreading branches and large foliage; a very rapid grower. Price, 6 to 8 feet, $75 \mathrm{c}$ each.

Acer Saccharinum (Silver Maple).-A well-known tree of rapid growth; hardy; foliage bright green above and silvery white beneath. Price, 6 to 8 feet, $75 \mathrm{c}$ each.

Acer Saccharum (Sugar Maple).-A popular American tree of pyramidal form. Price, 6 to 8 feet, $75 \mathrm{c}$ each.

Ailanthus glandulosa (Tree of Heaven.)-An ornamental tree from Japan of rapid growth. Its long, elegant, feathery foliage is excellent for producing tropical effects. Price, 50e each.

American Elm.-See Ulmus Americana.

Azalea Pontica.-This is one of the most beautiful varieties of hardy shrubs. Their flowers vary from the purest white to the most gorgeous scarlet and crimson; sweetly fragrant. Price, $\$ 1.00$ each.

Azalea Sinensis.-The flowers are larger and of more perfect form than those of Azalea Pontica, and resemble in form and size the flowers of the Azalea Indica. Their gorgeous colors vary from yellowish white, rose, all shades of yellow to richest orange. Large, strong, bushy named plants. Price, $\$ 1.00$ each.

Beech.-See Fagus sylvatica purpurea. 
Betula Alba (Birch, European White).-Remarkable for its elegance; very graceful, with silvery bark and slender branches. Price, 4 feet, $50 \mathrm{c}$ each; 6 to 8 feet, $75 \mathrm{e}$ each.

Birch, Cut-Leaved Weeping.-A charming tree, with deeply laciniated foliage. Its tall, slender, yet vigorous growth, graceful drooping branches, silvery white bark and delicately cut foliage, present a combination of attractive characteristics rarely met with in one tree. Price, 6 to 8 feet, $\$ 1.00$ each.

Catalpa speciosa.-Leaves large, heart-shaped; of rapid growth; flowers come in long grape-like clusters of white and purple, very fragrant. The timber obtained from this tree is valuable. Price, 6 to 7 feet, $75 \mathrm{c}$ each.

Cercis Canadensis (Judas Tree).-Produces pink blossoms all along the branches in early spring, before the appearance of the leaves. Much admired. Price, 4 to 6 feet, $75 \mathrm{c}$ each.

Cornus florida (Flowering Dogwood).-A tree of beautiful foliage, growing from 20 to 25 feet high and producing white flowers 3 inches in diameter early in the spring before the leaves appear. The foliage turns a deep red in autumn, making the tree one of the most beautiful in its season. Price, $50 \mathrm{c}$ each.

Crab Apple (Bechtel's Double Flowered).-Very showy spring flowers. Price, $50 \mathrm{e}$ each.

Crataegus Oxyacantha (Hawthorn).-A beautiful looking tree, clean in habit, fragrant and very delightful for sidewalks and gardens. Double in white, red or pink colors. Price, 6 feet, $75 \mathrm{c}$ each.

Cydonia Japonica (Japan Quince). - Its searlet flowers are very ornamental. Price, 25e each.

Deutzia gracilis.-This variety is dwarf-growing and produces its pure white flowers in prodigal luxuriance. Price, 35e each.

Deutzia scarba.-The Deutzias are among the showiest of our shrubs, producing their flowers all along the branches in the springtime. This variety has single white flowers, suffused pink. Price, 35e each.

Dogwood, Flowering.-See Cornus florida.

Exochorda grandiflora (Pearl Bush).- A very hardy shrub about 6 to 8 feet high, with dazzling white flowers when in bloom. Price, 6-inch pots, $50 \mathrm{e}$ each.

Fagus sylvaticus, Var. purpurea (Purple-Leaved Beech).-An elegant, vigorous tree; foliage deep purple, changing to crimson. Price, 2 to 3 feet, $50 \mathrm{e}$ earh.

Forsythia viridissima (Golden Bell).-A very singular and quite ornamental shrub. It flowers in early spring before the leaves appear, and is covered with bright yellow, pendulous flowers. Price, 35e pach.

Genista tinctoria (German Broom).-A very decorative shrub, with its drooping branches and fragrant yellow flowers. Price, 5-inch pots, 35e each.

German Broom.-See Genista tinctoria.

Ginkgo biloba (Maidenhair Tree).-A Japanese ornamental tree, with leaves resembling those of the Maidenhair Fern: valuable for street and avenue planting. Price, 3 to 4 feet, $75 \mathrm{c}$ each.

Golden Bell.- See Forsythia viridissima.

Golden Chain.-See Laburnum.

Gold Flower.-See Hypericum.

Hawthorn. - See Crataegus.

Hypericum Canariensis. -This grows about 4 feet high and has very ornamental yellow flowers. Price, 5-inch pots, 50e each.

Hypericum floribundum.-A very desirable tall-growing shrub, remarkable for the abundance of its golden-yellow flowers. Price, 3-inch pots, 25e each.

Hypericum Moserianum (Gold Flower).-Produces long, slender, inuch brancheil stems, leafy to the base and all drooping towards the ends; it is ma:velously free flowering, of large size, measuring from 2 to $21 / 2$ inches in diameter; in color a rich golden yellow, which is rendered still more effective by the numerous yellow stamens and crimson anthers; blooms continuously the entire season. Price, strong plants, 35e each.

Iochroma tubulosa.- A shrub ornamental for its blue tube-like flowers, especially attractive to humming birds. Price, 4 -inch pots, 35e each; 5-inch pots, 50e each.

Japanese Quince.-See Cydonia Japonica.

Japanese Snowball.-See Viburnum.

Judas Tree.-See Cercis Canadensis. 
Kerria Japonica (Single Flowers).-An ornamental spring flowering shrub with slender drooping branches and yellow single flowers. Price, 4-inch pot?, $25 \mathrm{c}$ each; 6-inch pots, 50c each.

Kerria Japonica (Double Flowers).-A spring flowering shrub with slender, upright branches and double yellow rose-form flowers. Price, 4-inch pots, 25e each; 6-inch pots, j0c each.

Laburnum, or Golden Chain.-A beautiful small-growing tree, with long, drooping racemes of fragrant yellow flowers. Price, 4 to j fee-, 50c each.

Large-Leaved Maple.-See Acer nacrophyllum.

Lemon Verbena.-See Lippia citriodora.

Lilac.-See Syringa.

Linden.-See Tilia.

Lippia citriodora (Lemon Verbena).-This ornamental plant is a favorite because of its sweet-scented flowers and foliage. Price, 25c and 50c: each.

Maidenhair Tree.-See Ginkgo biloba.

Mock Orange.-See Philadelphus coronarius.

Pearl Bush.-See Exochorda grandiflora.

Philadelphus coronarius (Syringa, Mock Orange). - A delightfully fragrant shrub with large white flowers. It blooms until the middle of summer. Price, 50c each.

Populus alba (White Poplar).-A tree of wonderfully rapid growth and spreading habit. Leaves dark rich green above and white beneath. Price, 7 Je each.

Prunus Pissardi (Purple-Leaf Plum).-The tree is a decided contrast in itself. The leaves as they first appear on the tips are a beautiful orange color, and mature to a rich purple, growing darker as the season advances. Its pink flowers and bright red fruit altogether make it the most rich and beautiful ornamental tree possible. Price, 75c each.

Purple-Leaved Beech.-See Fagus.

Purple-Leaved Plum.-See Prunus Pissardi.

Salix Babylonica (Weeping Willow).-One of our most popular willows, forming a large tree with drooping branchlets. Price, 4 to 6 feet, $50 \mathrm{c}$ each.

Scarlet Thorn.-See Crataegus coccinea.

Silver Maple.-See Acer saccharinum.

Snowball.-See Viburnum.

Snow Berry.-See Symphoricarpus.

Spanish Broom.- See Spartium junceum.

Spartium junceum (Spanish Bloom).-The handsome yellow flowers, arranged in racemes at the ends of the twigs, are highly perfumed. Price, 5-inch pots, $50 \mathrm{c}$ each.

St. John's Wort.-See Hypericum.

Sugar Maple.-See Acer saccharum.

Symphoricarpus racemosus (Snow Berry).-This has pinkish flowers, which are succeeded by large white berries. A very remarkable and ornamental bush until winter. Price, 4-inch pots, 25c each.

Syringa, or Mock Orange.-See Philadelphus coronarius.

Syringa (Lilac).-Frau Bertha Dammann. This produces the largest clusters of purest white lilac. Price, 2 feet high, 50c each.

Syringa (Lilac).-Madame Ludwig Spaeth. Panicle long, with large individual flowers; single; color a fine dark purple-red. Price, 50c each.

Syringa (Lilac).-President Grevy. Beautiful blue flowers, very double and very large. One of the finest lilaes. Price, 50c each.

Tilia Europaea (Linden).-A fine pyramidal tree with large leaves; valuable for street and lawn planting. Price, 75c each.

Tree of Heaven.-See Ailanthus glandulosus.

Ulmus Americana (American Elm).-One of the grandest and hardiest of our park or street trees. Price, 75े each.

Viburnum tomentosum plicatum (Japanese Snowball). - This variety blooms in June, and for a long time is a solid mass of white, the plants being completely covered. Price, 75c each.

Weeping Willow.-See Salix Babylonica.

White Poplar.-See Populus alba. 


\section{EVERGREEN TREES AND SHRUBS.}

Abutilon (Flowering Maple). - We have these attractive shrubs in three shades, white, yellow and red. Price, 4-inch pots, 25c each; 6-inch jots, 50c cacli.

Acacia armata (Kangaroo Thorn).-A low-growing shrub of drooping habit, with triangular leaves and the stipules reduced to prickles; flowers yellow, sweet-scented. Price, 4-inch pots, $25 \mathrm{c}$ each.

Acacia Baileyana.-One of the best Acacias, with its beautiful, feathery gray foliage; flowers sweet-scented, in heavy clusters; grows 12 to 14 feet in height. Price, 50c each.

Acacia longifolia (Sydney Golden Wattle).-A tall, handsome shrub, witl golden yellow flowers. Useful as a street tree. Price, 60c each.

Acacia melanoxylon (Australian Blackwood).- One of our popular strect trees, making a fine pyramidal tree, which bears pruning or mutilation for telephone wires. Price, 50c and $75 \mathrm{c}$ each.

Acacia mollissima.-A fine, erect-growing tree, with glaucous green, feathery foliage; flowers yellow, produced in early spring in great profusion. A rapid-growing tree. Price, 2 to $2 \frac{1}{2}$ feet, $35 \mathrm{c}$ cach; 3 to \pm feet, $60 \mathrm{c}$ each.

Acacia pycnantha (Golden Wattle).-A small tree which deserves more wide planting in California on account of its profusion of yellow flowers in early spring. Price, 25c each.

Acacia verticillata.-A very ornamental shrub, with dark green foliage and yellow fragrant flowers in spikes. Price, 25c each.

Albizzia lophantha.-Ornamental, with graceful, feathery foliage and yellowish flowers. Price, 6-inch pots, 60c each.

Angel's Trumpet.-See Dature suaveolens.

Araucaria Bidwelli.-Branches in regular wlorls; closely set with spiny, shining, deep-green leaves. Very handsome for the lawn. Thrives well here. Price, balled, 3 to $31 / 2$ feet, $\$ 2.50$.

Araucaria excelsa (Norfolk Island Pine).-One of the handsomest of all trees; pyramidal in form and very symmetrical; lardy in protected locations. Excellent for parlor decorations. Price, 8 to 12 inches, $\$ 1.00 ; 1$ to 2 feet, $\$ 2.00$ each.

Araucaria imbricata (Monkey Puzzle).-This tree is attractive on account of the arrangement of the branches, which grow in distinct whorls about the central stem. Price, 1 foot, $\$ 1.00$ each.

Arborvitae (Compact).- See Thuya occidentalis, Var. nana.

Arborvitae (Pyramidal).--See Thuya occidentalis pyramidalis.

Arundo Donax (Giant Reed).-Very ornamental; may be used to produce a tropical effect or to hide unsightly objects on account of its rapid growtl. Price, $10 \mathrm{c}$ per root.

Arundinaria falcata (Bamboo).-Not over 15 feet high, with thin stems and a mass of feathery foliage; grows in clumps, but never sends out runners. Price, 50c each; in tubs, $\$ 1.00$.

Arundinaria Japonica (Bamboo).-Thin stems, broad leaves, and grows to a height of 10 feet. Is suitable for tubs and is very decorative. Price, 50c per root; in tubs, $\$ 1.00$.

Aucuba Japonica.- "Gold-Dust Tree," on account of its large glossy foliage being marked with yellow spots. It is an extremely beautiful plant, and is of slow, spreading growth. In the warmer sections it should have partial shade. Price, 6-inch pots, 50c each.

Australian Blackwood.-See Acacia melanoxylon.

Azalea Indica.-A hardy flowering shrub noted for its beauty and fragrance. Price, \$1.00 each.

Bamboo.-See Arundinaria.

Bamboo.- See Phyllostachys Henonis.

Berberis Darwini.-A shrub with handsome holly-like leaves and yellow flowers. Price, $40 \mathrm{c}$ each.

Blue Gum.-See Eucalyptus globulus.

Blue Spirea.-See Caryopteris Mastacanthus.

Box.-See Buxus.

Breath of Heaven.-See Diosma.

Brush Cherry.- See Eugenia myrtifolia.

Buxus sempervirens aureum (Box).-Desirable for borlers or elging; leaves blotched with yellow. Price, 50c per dozen. 
Buxus sempervirens suffruticosa (Box).-A dwarf variety of evergreen shrub, used for borders and edging. Price, 50e per dozen.

Camelia Japonica.-A showy Japanese shrub, familiar to nearly everyone. They bloom early in springtime and are a great aequisition to the garden. The waxy, odorless flowers are produced very freely. We offer the double white, double pink, double red. Price, $\$ 1.00$ each.

Camphora officinalis (Camphor Tree), - A fast-growing, very symmetrical, ornamental tree, thriving in the very poorest soil. A native of Japan. Bright green foliage; well adapted for lawn purposes. Price, 60e each.

Camphor Tree.-See Camphora officinalis.

Cantua buxifolia.-Drooping branches and bright crimson flowers tinged with yellow make this very ornamental. Price, 50c each.

Caryopteris Mastacanthus (Blue Spirea).-Very striking when in bloom on account of its mass of blue flowers; grows from 2 to 3 feet high. Price, 35c each.

Cassia tomentosa.-A low-growing shrub blooming in winter and spring. Its deep yellow flowers and dark green foliage make it very effective for garden and avenue. Price, $50 \mathrm{c}$ each.

Cedar.-See Cedrus Deodara.

Cedrus Deodara (Cedar).--Exceedingly handsome, with drooping branches and silvery, green foliage, forming a dense network. Perhaps the grandest of coniferous trees. Succeeds admirably in warm sections. Of very rapid growth. Price, 3 to 4 feet, $\$ 2.50$.

Cestrum fasciculatum.-A tall-growing shrub, commonly called Japanese Fuschia. Very showy with its bright red flowers, which resemble those of a fuschia. Price, 50c each.

Chamaecyparis Lawsoniana (Lawson Cypress).-This California species has great beauty. It is of rather an upright growth; the branches droop gracefully, and the foliage is of a lovely sea-green color. Price, 4 to 5 feet, $\$ 2.00$.

Chilean Guava.-See Mrrtus.

Choisya ternata.-A handsome white-flowered sweet-scented shrub. Price, in 6 -inch pots, $50 \mathrm{c}$ each.

Chrysanthemum frutescens (Marguerite).-Bushy; suitable along fences and in sheltered corners. Flowers large and in abundance. Colors in white and yellow. Price, $15 \mathrm{c}$ and $25 \mathrm{c}$.

Cistus ladaniferus (Rock Rose).-Well adapted for rockeries with southern exposures, and for stone walls. Price, 35c each.

Coccoloba.-See Muehlenbeckia platyclados.

Coffee Berry.-See Rhamnus Californica.

Crimson Flowered Eucalyptus.-See Eucalyptus ficifolia.

Cupressus macrocarpa (Monterey Cypress).-A native of California, and one of the most desirable of evergreens. Very extensively planted for hedges. Price, 3-inch pots, $15 \mathrm{e}$; 5 -inch pots, $35 \mathrm{c} ; \$ 2.00$ per 100 , in boxes.

Datura suaveolens (Angel's Trumpet).-Flowers large, white, double; very fragrant. Needs a sheltered place. Price, $50 \mathrm{c}$ each.

Diosma vulgaris rubra (Breath of Heaven).-A handsome little shrub, with heath-like foliage and small, white, star-shaped flowers. The leaves when bruised emit a sweet perfume. Price, 6-inch pots, 50c each.

Duranta Plumieri (Golden Dew Drop).-The best evergreen shrub with a great profusion of blue flowers. The yellow seeds hang between the branches like dew drops. Price, 50c each.

Dusty Miller.-See Senecio Cineraria.

Erica Mediterranea (Heath).-Very much esteemed for its abundance of sweet flowers and early spring bloom. Has an upright, compact habit. Price, $50 \mathrm{c}$ each.

Escallonia pulverulenta.-A very elegant evergreen shrub. Very striking when in flower, as the white blooms cover the whole bush. Price, 6-inch pots, $50 \mathrm{c}$ each.

Escallonia rubra.-An excellent ornamental shrub used for hedges or for windbreaks. Foliage glossy and flowers deep red. Price, 6 -inch pots, 50c each.

Eucalyptus ficifolia (Crimson Flowered Eucalyptus).-An ornamental lawn tree with its red clusters of flowers. Slow growing. Price, $50 \mathrm{c}$ each.

Eucalyptus globulus (Blue Gum).-This well-known tree is noted for its quick growth and valuable timber. Price, in boxes, $\$ 4.00$ per hundred. 
Eucalyptus viminalis (Manna Gum).-A tall, graceful tree. Stands considerable frost and is a valuable bee food. Price, in boxes, $\$ 4.00$ per hundred.

Eugenia myrtifolia (Brush Cherry).-One of the rarest and best ryramidal evergreens; elegant when in flower. Its fruit is edible. Price, 4-inch pots, 3 亏̄c eacli.

European Holly.-See Ilex Aquifolium.

Euonymus Japonicus aureus. - This hardy . Tapanese shrub should have a place in the garden on account of its variegated foliage of gold and silver. Price, 4 -inch pots, 35c each; 6-inch pots, 50c each; in tubs, 2 feet, $\$ 1.00$ each.

Ficus macrophyllum. - A hardy outdoor rubber tree. Foliage large, handsome. glossy, leather-like. Price, 75̄ each.

Field Oak.- See Quercus agrifolia.

Flowering Maple.-See Abutilon.

Fuchsia.-Prince of Wales. A large double variety. Price, 35e and 5uc each.

Fuchsia Richardia (Baby Fuchsia).-A shrubby fuchsia with baby red flowers. Very showy in the background of the garden. Price. 25c and 3.5.

Fuchsia (Storm King).-A double variety; white, witl rerl center. Price, 25c: and $35 \mathrm{c}$ each.

Fuchsia.-Single flower in four different colors. A fast grower and very hardy. Price, 25c and $35 \mathrm{c}$ each.

German Broom.-See Genista tinctoria.

Genista tinctoria (German Broom).-A very decorative shrub, with its drooping branches and fragrant yellow flowers. Price, 5-inch pots, 35c each.

Giant Reed.-See Arundo Donax.

Golden Arborvitae.-See Thuya.

Golden Dewdrop.- See Duranta Plumeri.

Gold Dust Tree.-See Aucuba Japonica.

Golden Wattle.-See Acacia pycnantha.

Gold Flower.-See Hypericum.

Grevillea robusta (Silk Oak).-A graceful fern-leaved tree, suitable for lawns. Price, 4 to 5 feet, $75 \mathrm{c}$ each.

Grevillea Thelemanniana.-A small shrub desirable for its scarlet flowers. Requires a dry, warm place. Price, 4-inch pots, $50 \mathrm{c}$ each.

Gum Tree.-See Eucalyptus globulus.

Heath.-See Erica Mediterranea.

Heliotropium Peruvianum (Heliotrope). - A general favorite because of its delicious fragrance and compact mass of bloom. We have heliotrope both dark and light in color. Price, small flowers, 25e each; large, 35c each.

Holly.-See Ilex Aquifoliun.

Hydrangea Hortensis.-Very showy plants with large foliage and white-pink flowers in large, attractive clusters. Price, strong plants, 25c and 35c.

Ilex Aquifolium (European Holly).-A small tree with shining dark green leaves and bright scarlet berries. Somewhat resembles the oak in form. Price, 4-inch pots, 35e; 2 to $21 \%$ feet, ballerl, $\$ 1.50$.

Islay.-See Prunus ilicifolia.

Iochroma tubulosa.-A shrub ornamental for its blue tube-like flowers, especially attractive to humming birds. Price, 4 -inch pots, $35 \mathrm{c}$ each; 5 -inch pots, $5\left(\right.$ ce $^{\circ}$ each.

Irish Juniper.-See Juniperus communis Hibernica.

Jacobinia magnifica Var. carnea (Justicia earuea).-Broad ornanental leaves. Flowers in showy, rose-colored, spike-like thyrses. Price, 25e each.

Jacobinia pauciflora.-A liwarf shrub with light green folige. Covered with mumerous tubmlar red and yellow flowers from early spring to late summer. Price, 25c each.

Juniper.-See Juniperus.

Juniperus communis Hibernica (Trish Juniper).-Erect pramialal form. Deep green foliage. Price, 2 feet, $\$ 1.00$ each.

Juniperus prostrata (Juniper). $-\Lambda$ ereeping variety suitable for covering terraces and banks. Price, 4-inch pots, 35c eavh.

Kangaroo Thorn.-See Acacia armata.

Laurestina.-See Viburnum 'Tinus.

Lavender. $\Lambda$ valuable plant for every garden amil home. Price, 3 -inch pots. $20 \mathrm{c}$ each; 6-inch pots, 35c each.

Lawson Cypress.- See Chanıecyparis Lawsoniana. 
Leonotis Leonurus (Lion's Ear).-A very ornamental, freely-blooming shrub with showy scarlet flowers. Price, 4-inch pots, 35c each; 6-inch pots, $50 \mathrm{c}$ each.

Leptospermum laevigatum.-An evergreen shrub desirable for its drooping habit. Price, 4 -inch pots, $35 \mathrm{c}$ each.

Ligustrum Japonicum (Privet).-The hardiest of the flowering shrubs and remarkable for the beauty and persistence of its foliage. Largely used as ornamental hedges. Price, 3 -inch pots, $15 \mathrm{c}$ each; 5 -inch pots, $25 \mathrm{c}$ each.

Ligustrum ovalifolium (California Privet).-This is extensively used for hedges in ornamental gardens, owing to its being able to bear clipping without injury. Price, 5-inch pots, $25 \mathrm{e}$ each.

Lion's Ear.-See Leonotis Leonurus.

Magnolia grandiflora.-The most noble and best American evergreen tree; remarkable for the majesty of its form, the magnificence of its foliage and beauty of its flowers. Price, 6-inch pots, $\$ 1.00$ each.

Malvastrum mollis.-A fast-growing shrub with scarlet flowers. It is a constant bloomer. Ornamental. Price, 4 -inch pots, 35e; 5 -inch pots, 50c.

Manna Gum.-See Eucalyptus Viminalis.

Marguerite.-See Chrysanthemum frutescens.

Matilija Poppy.-See Romneya Coulteri.

Maytenus Boaria (Smilax Tree, Mayten).-A beautiful evergreen tree with long, drooping branches. Price, in 3 -inch pots, $25 \mathrm{c}$ each; 4 -inch pots, 35c.

Monkey Puzzle.-See Araucaria imbricata.

Monterey Cypress.-See Cupressus macrocarpa.

Muehlenbeckia platyclados Coccoloba.-So called on account of its strange appearance of shining flattened stems, which give it a tropical effect. Stands more abuse than any other plant; will grow with very little water either out of doors or in. Price, 6-inch pots, 50c.

Myrtus Ugni (Chilean Guava). - A very pretty evergreen shrub with a strong herb-scented odor. Price, 3 -inch pots, $20 \mathrm{c}$ each; 4 -inch pots, $35 \mathrm{c}$ each.

New Zealand Flax.-See Phormium tenax.

Nerium (Oleander). - A beautiful shrub with dark green leather-like foliage. Blooms in abundance; flowers in two colors, white and pink. Price, 5-inch pots, $35 \mathrm{c}$ each.

Norfolk Island Pine.-See Araucaria excelsa.

Oleander.-See Nerium.

Pepper Tree.-See Schinus molle.

Phormium tenax (New Zealand Flax).-A subtropical bedding plant, either in single color or variegated. Very ornamental in tubs for porches and house. Price, in pots, $75 \mathrm{c}$ each.

Phyllostachys Henonis (Bamboo).- Highly recommended for garden and porch decoration. Yellow stems and light green foliage. Very graceful. Price, $50 \mathrm{c}$ clump; in tubs, $\$ 1.00$ each.

Pittosporum engenioides (Tarata).-The light green foliage makes this tree very ornamental. It is much used for hedges. Price, 3 -inch pots, 15c, $\$ 1.50$ per dozen; 4 -inch pots, $25 \mathrm{c}, \$ 2.50$ per dozen; 5 -inch pots, $50 \mathrm{c}$; extra large, $75 \mathrm{c}$ each.

Pittosporum nigra (Tenuifolium).-Its small dark green foliage gives this tree a good appearance. Used as ornamental hedges and as a sidewalk tree. Price, in 3 -inch pots, $15 \mathrm{c}$; 4 -inch pots, $25 \mathrm{c}$; 5 -inch pots, $50 \mathrm{c}$ each; extra large, 6 to 8 feet, $75 \mathrm{c}$ each.

Pittosporum undulatum.- It has large green glossy leaves and the flowers are sweet scented like orange blossoms. Price, in 4 -inch pots, 35c; 5-inch pots, $50 \mathrm{c}$.

Polygala Dalmaisiana.-A fine shrub, three to four feet high, which blooms nearly all summer. Price, 5 -inch pots, $35 \mathrm{c}$ each.

Privet.-See Ligustrum.

Prunus ilicifolia (Islay, California Evergreen Cherry).-This is the best evergreen tree California has. Pyramidal in habit with glossy leaves. Price, 5 -inch pots, 50c each.

Quercus agrifolia (Field Oak).-An evergreen slow-growing ornamental oak. Price, 5-inch pots, $\$ 1.00$ each.

Redwood.-See Sequoia sempervirens.

Rhamnus Californica (Coffee Berry).-A hardy delightful evergreen tree with a pyramidal form. Price, 5-inch pots, $50 \mathrm{c}$ each, 
Rock Rose.-See Cistus 1 adaniferus.

Romneya Coulteri (Matilija or California Tree Poppy).-Grandest of California flowers, with its pure white petals and yellow center. No garden should be without it. Will open for many months in grand display; will grow in many kinds of soil, although sandy soil is the best, and will stand considerable frost under slight protection. Price, in pots, $\$ 1.50$ each.

Rosmarinus officinalis (Rosemary).-A dwarf shrub with light blue flowers. Well suited for hedges, rockeries and dry places. Price, 4-inch pots, 25e each; 6 -inch pots, 35e each.

Rubber Tree.-See Ficus Indica.

Schinus molle (Pepper).-A very ornamental street tree and for the garden. Its graceful foliage and drooping habit make it valuable. Price, 3 to 4 feet, $50 \mathrm{c} ; 4$ to 6 feet, $7 \tilde{\mathrm{c}}$.

Senecio Cineraria (Dusty Miller).-Its light gray foliage is very showy. Price, 4-inch pots, 20c each.

Senecio grandiflorus.-It is very ornamental in foliage; also bears a inass of flowers. Price, 35e each.

Sequoia sempervirens (Coast Redwood). - Its ornamental habit and pyramidal form make it delightful for large grounds or lawns. Price, 5-inch pots, $50 \mathrm{e} ; 6$-inch pots, $75 \mathrm{c}$.

Silk Oak.-See Grevillea robusta.

Smilax Tree.-See Maytenus Boaria.

Swainsona galegifolia.-An Australian shrub with deep red flowers and light green foliage. Price, 35c.

Swainsona galegifolia Var. Albiflora.-This white variety is a profuse bloomer. Price, $50 \mathrm{e}$ each.

Sydney Golden Wattle.-See Acacia longifolia.

Tagetes Lemmoni.-A low-growing shrub strongly scented like Lemon Verbena and with yellow flowers like Marigold. Price, 3-inch pots, 25e.

Tarata.-See Pittosporum.

Thuya occidentalis aurea (Golden Arborvitae).-A hardy, free grower with fine golden-ycllow foliage; most desirable. Price, balled, 1 to 2 fcet, $\$ 1.00$ each.

Thuya occidentalis nana (Compact Arborvitae).-Bright light green foliage with dwarf and compact habit. Price, balled, 1 to 2 feet, $\$ 1.00$ each.

Thuya occidentalis pyramidalis (Pyramidal Arborvitac). - The most crect and compact of all the species. Foliage deep green; perfeetly hardy. Price, balled, 1 to 2 feet, each.

Veronica Andersonii.-A hardy, ornamental plant with blue flowers. Foliage glossy and evergreen. Price, 5-inch pots, 35e each; 6-inch pots, 50e each.

Veronica speciosa Var. imperialis. - A half hardy plant with erimson-purple flowers and large glossy leaves. Price, 4-inch pots, 35e each; 6-inch pots, $50 \mathrm{c}$ each.

Viburnum Tinus (Laurestina).-An evergreen hardy shrub with white, flowers that are rose-colored when in bud. Desirable for hedging and fences. Price, 50e each.

\section{ROSES.}

The roses we offer are healthy 2-year-old strong plants in dormant condition from November 1st to April 1st. $25 \mathrm{e}$ each; $\$ 2.50$ per dozen. After April 1st, in pots only, at $30 \mathrm{e}$ each.

Abbreviations: T., Tea; II. T., Hybrid Tea; II. P., Hybrid Perennial; B., Bourbon; C., China; P., Polyantha.

Agrippina, C.-A constant bloomer; much esteemed for hedges. Rich erimson. American Beauty, II. P.-Targe, globular. Rosy crimson, shaded earminc. Delicious odor. A fine variety for forcing.

Anne de Diesbach, H. P. (Glory of Paris).-Deep earmine, shaded with maroon. Long, pointed buds and large, eompact flowers.

Anna Oliver.-Creamy blush, shaded with deep carmine, tinged and edged with silvery rose. Very large, full and double. An excellent sort. 
Baby Rambler, or Mme. N. Levavasseur, P.-Dwarf ever-blooming. Flowers in large clusters of brightest crimson.

Baron de Bonstetten, II. P.-Splendid large flowers; very double and full. Color, a rich dark red, passing to a velvety maroon. Highly seented and very beautiful.

Belle Siebrecht, H. T.-A superb pink rose. The buds are long and pointed, and when half blown the petals reflex in a graceful manner. The flowers have great substance and the petals are of heavy texture.

Bride, T.-An ever-blooming, pure white tea rose, of large size and most perfect form.

Bridesmaid, T.-This is an exquisite tea rose and at all seasons is a clear delicate pink. Very fine buds.

Captain Christy, H. P.-Of delicate flesh color, rosy center. Flowers extra large, double, full and sweetly scented.

Catherine Mermet, T.-A bright rosy flesh color. Perfect in bud and flower. Flowers large and full.

Cecile Brunner, P. ("Baby Rose").-A charming, fairy-like variety of sweet, delicate fragrance. Color, salmon pink, with deep salmon center. Free bloomer.

Cornelia Cook, T.-Flowers creamy white, forming very large buds, borne on heavy stems; very distinct and beautiful.

Duchess de Brabant, T.-Better known as "The Duchess." One of the most popular roses. Beautiful rosy blush; delicate and graceful. A free bloomer and deliciously fragrant.

Frau Karl Druschki, H. P.-The finest new white. Large pure white blooms. Vigorous grower.

Gen. McArthur.-Color the most brilliant shade of crimson, retaining its brilliancy when fully expanded. Very sweet and easy to grow.

Gen. Jacqueminot, H. P.-Rich velvety crimson, changing to scarlet crimson. A magnificent rose, beautiful in the bud or open. Is without a rival in fragrance and richness of color.

Gloire Lyonaise, H. T.-The new hybrid tea. Color, creamy yellow with white on edge of petals. Growth very free; upright stems. A very desirable rose. One of the best lately sent out.

Golden Gate, T.-Flowers delicately shaded. Highly commendable in all respects.

Gruss an Teplitz, or Greeting of Teplitz, H. T.-As a bedding rose, this is one of the finest and most useful varieties ever sent out. The color is brightest scarlet, shading to deep, rich, velvety crimson. It is very fragrant.

Kaiserin Augusta Victoria, H. T.-One of the finest white roses. Flowers, borne on long, heavy stems, of pure ivory white. Long, pointed buds. A good grower and a fine bloomer. A popular favorite.

Killarney, H. T.-Growth upright and strong. Bloom of good size, not very full. Very handsome in bud. Graceful and unique when in full bloom. Color pink, changing to flesh.

La France, H. T.-Color, satin pink; outer petals pale flesh. Has the free blooming qualities of the tea rose, and is perfectly hardy. Very fragrant, distinct and beautiful. One of the most useful of all roses.

Liberty, H. T.-Crimson scarlet in color and one of the best roses for cut flowers. Buds perfect, on strong stems; fragrant. Constant bloomer.

Madame Caroline Testout, H. T.-Both flowers and buds are extra large and of very fine appearance. Resembles La France, but of stronger habit. Free flowering. The color is brilliant satiny rose, deepening at center.

Madame Lambard, T.-A reliable rose; silvery pink. Very free in bloom, and double at all times.

Magna Charta, H. P.-Bright clear pink, flushed with crimson. Flowers large, very double and full. A fragrant rose, goor for forcing.

Maman Cochet (pink), T.-Deep pink. Buds large, long and pointed; of great substance. A continuous bloomer. Plant very vigorous, healthy.

Maman Cochet (white), T.-Same as above, only pure white in color, occasionally tinged with blush on the outer petals.

Marie Van Houtte, T.-White, slightly tinted yellow; petals often edged with rose. Flower quite full and well former. A good rose both in bud and open. Reliable; one of the best of its class. 
Meteor, H. T.-Color, rich velvety crimson; very bright and striking. The flowers are large and regular and perfectly double. It is a constant and profuse bloomer and very fragrant.

Mrs. John Laing, H. P.-An elegant new hybrid perpetual rose; color, clear soft pink. The buds are long and pointed, and the flowers extra large and full, borne on long stems. Deliciously fragrant.

Niphetos, T.-An elegant pure white rose. The buds are long and pointed. Free flowering.

Papa Gontier, T.-A splendid variety. The buds are extra large, finely formed and very beautiful. Color, cherry red, passing to crimson. Useful as a winter bloomer.

Paul Neyron, H. P.-Extra large and full; fine form. Deep carmine color; very fragrant. Free bloomer. An excellent rose.

Prince Camile de Rohan, H. P.-Rich, dark, velvety erimson, ehanging to scarlet inaroon. Full, double and sweet.

Rainbow Improved, T.-The color is a lovely shade of deep coral pink, beautifully striped and mottled in the most unique manner with intense glowing crimson, elegantly colored at center with rich golden amber. Makes beautiful buds, and the flowers are extra large, very sweet and of great depth and substance. The best striped rose in cultivation.

Safrano, T.-One of our old favorites. Constant bloomer; elegant in bud. Buff and apricot.

Souvenir de Pres. Carnot, H. T.-This is a superb rose in every way. The flowers are large, full and double, exquisitely shaped and with heavy, thick and shell-like petals. Color a delicate rosy blush shaded deeper to the center of the flower. Long, pointed buds.

Ulrich Brunner, H. P.-This we consider one of the most satisfactory of all the Hybrids. Flowers large, full and sweet. Color, bright clear red. A profuse bloomer and hardy grower. groups.

For the convenience of buyers we give below a list of bush roses in color

White.-Bride, Cornelia Cook, Kaiserin Augusta Victoria, Maman Cochet, Frau Karl Druschki, Niphetos.

Red.-Agrippina, American Beauty, Baron de Bonstetten, Madame Caroline Testout, Papa Gontier, Paul Neyron, Ulrich Brunner, Anna De Diesbach, Baby Rambler, Gen. MeArthur, Gen. Jaequeminot, Liberty, Prince Camile de Rohan, Meteor, Gruss an Teplitz.

Pink.-Belle Siebrecht, Bridesmaid, Captain Christy, Catherine Mermet, Cecil Brunner, Duchess de Brabant, Killarney, La France, Madame Lambard, Magna Charta, Maman Cochet, Mrs. John Laing, Rainbow Improved, Sov. de Pres. Carnot.

Yellow.-Gloire Lyonaise, Golden Gate, Marie van Houtte, Safrano.

\section{CLIMBING ROSES.}

Banksia White.-Thornless; small, sweet flowers in bunches; very rampant grower.

Banksia Yellow.--Same as the preceding flower; bright yellow; good bloomer.

Beauty of Glazenwood (also known as the San Rafael Rose).-Flowers bright coppery yellow, borne in large clusters. A free grower and splendid bloomer in the spring time.

Cherokee, Single.-One of the finest pillar roses in cultivation. Large, clear white, single flowers, full of bright yellow stamens in center, which give it a most unique appearance. Foliage dark, rich green. A most vigorous grower.

Climbing Bridesmaid, T.-A strong, rapid grower and free bloomer; elear dark pink. A superb variety.

Climbing Cecil Brunner (Pol.).-This is a sport of that famous rose "Cecil Brunner," and is identical with it except that it is a strong climber, throwing up shoots ten to twelve feet high in a single season. The flowers are very fragrant and of a lovely salmon-pink with dark center, and are produced in great abundance. 
Climbing Kaiserin Augusta Victoria, H. T.-Buds long and pointed. Pure white, of superb substance and texture. A strong and rapid grower.

Climbing Mad. Caroline Testout, H. T.-New and a most grand acquisition. - Bloom identical with its parent, the bush sort. One of the strongest of climbers and a good-sized plant; in full bloom makes a truly gorgeous sight in all respects. Bloom, beautiful solid pink coloring.

Climbing Meteor, H. T.-The brightest color of all climbing roses. Its flowers are much larger than Meteor and are richer in color.

Climbing Nephitos, T.-Flowers very large; buds long and pointed. Color, purest white. Plants of strong, vigorous growth.

Climbing Papa Gontier, T.-Color the same as the bush form. It is a rapid climber and more hardy than its parent.

Climbing Perle des Jardins, T.-Habit of growth is vigorous, young plants often sending up shoots six to eight feet high in one season, with rich, glossy foliage and bright red stems. The flowers are produced in profusion and are deep canary yellow.

Climbing Wootton, H. T.-This is a sport of that famous rose, "Sov. de Wootton,' and is identical with it, except that it is a strong climber. The flowers are large, full and regular, with thick, leathery petals, and are bright magenta-red, passing to violet crimson.

Crimson Rambler (Pol.).-Flowers of brightest crimson and produced in great profusion on long, clean stems. A very free bloomer.

Dorothea Perkins, P.-A new rose, praised very highly in the East, where it originated. Of Crimson Rambler type, but much prettier foliage. Color, a pretty pink. A strong climber.

Glorie de Margottin, H. P.-Large flowers; deep, rich scarlet, and an excellent bloomer; good grower.

Glorie de Rosemont, or "'Ragged Robin." - Bright scarlet single flowers; a rapid climber.

La Marque, N.-Pure white buds, open flower tinged light canary yellow; large and full. A grand climber.

Marechal Niel.-One of the largest and most beautiful roses grown. Flowers extra large, very double and deliciously perfumed. Deep golden yellow. Buds of immense size.

Reve d'Or (Climbing Safrano).-Buff apricot-yellow; very free blooming. One of the best climbing roses in cultivation.

Reine Marie Henrietta, H. T.-An extra fine climbing variety. Flowers large, full and handsome. Color, clear cherry red. Grows best with plenty of sunshine, away from buildings, on trellis.

William Allen Richardson.-Coppery yellow, flushed with carmine. Flowers medium, full and fragrant.

Yellow Rambler (Pol.).-Clear golden yellow. One of the best of the Ramblers.

For the convenience of buyers we give below a list of climbing roses in color groups.

White.-Banksia, Cherokee, Cl. Kaiserin Augusta Victoria, Cl. Niphetos, La Marque.

Red.-Cl. Papa Gontier, Cl. Wootton, Gloire de Margottin, Gloire de Rosemont, Reine Marie Henrietta, Cl. Meteor, Crimson Rambler, Dorothy Perkins.

Pink.-Cl. Bridesmaid, Cl. Cecil Brunner, Cl. Madame Caroline Testout.

Yellow.-Yellow Banksia, Beauty of Glazenwood, Cl. Perle des Jardins, Marechal Niel, William Allen Richardson, Yellow Rambler.

\section{CLIMIBING VINES.}

Ampelopsis Quinquefolia (Virginia Creeper).-A good vine for clinging to walls. Foliage very showy in autumn, changing to various colors. Price, 3 -inch pots, 25 e each.

Ampelopsis Veitchii (Boston Ivy).-An excellent plant for climbing walls and chimneys and is especially admired in autumn on account of its scarlet foliage, the colors rivaling those of the maple when touched with frost. Price, 3-inch pots, 20e; 4-inch pots, 35c.

Bignonia buccinatoria.-A haudsome climber with scarlet flowers. Clings to walls like Ampelopsis, Price, 50e each. 
Bignonia. $-\Lambda$ fast grower with small pink flowers. Price, 5 -inch pots, 50e each.

Boston Ivy.-See Ampelopsis Veitchii.

Bougainvillaea glabra sanderiana.-A showy climber, the bracts forming the rosy red color of the flowers. Price, 60c each.

Clematis Henryi. $-\Lambda$ very large flowered species, white in color and fragrant. Price, $75 \mathrm{c}$ each.

Clematis Jackmani.- $\Lambda$ very large flowered species, blue in color and very fragrant. Price, 75e each.

Clematis montana.-An excellent climber; a fast grower and bears white flowers in abundance. Price, $75 \mathrm{c}$ each.

Clematis paniculata. - A rapid grower with very fragrant small white flowers. Price, 50e each.

Cobaea scandens. $-\Lambda$ very rapid grower with purple bell-shaped flowers. Price, $50 \mathrm{c}$ each.

English Ivy.-See Hedera.

rragaria Chilensis (Chilean Strawberry).-Especally graceful for walls or embankments. Price, $25 \mathrm{e}$ per dozen or $\$ 2.00$ per hundred.

Fuchsia procumbens (Trailing Fuchsia).-Desirable for hanging baskets, rockeries or window boxes. Price, $20 \mathrm{c}$ each.

German Ivy.-See Hedera.

Gnaphalium Lanatum.-An elegant plant with gray velvet foliage and not known in any nursery. An abundance of small white flowers. Price, 50c each.

Hedera Helix (English Ivy).-A fast grower, suitable for embankments, sand binding or to cover unsightly walls. Price, field grown, $10 \mathrm{c}$ each; in pots, $20 \mathrm{c}$ each.

Hedera (Scotch Ivy).- Small leaves, liardy and suitable for rock work. Price, $20 \mathrm{c}$ each.

Hedera (German Ivy).-Hardy; very showy for chimneys and walls. Foliage small, glossy. Price, 20e each.

Hedera (Variegated Ivy).-Elegant for baskets and house plants; leaves silver cdged. Price, 25e each.

Honeysuckle.-See Lonicera.

Hops.- See Humulus.

Humulus Lupulus (Hops).- Suitable for covering fences, porches and out buildings. One of the fastest growing vines for the purpose. Price, $10 \mathrm{c}$ root.

Ivy Geranium.-An ornamental vine for window boxes, hanging baskets, walls and fences. Colors, rose, light pink, purple and scarlet. Price, 5c to $25 \mathrm{c}$ each.

Jasmine.-See Jasminum.

Jasminum alba (Jasmine).-An elegant vine for trailing on pillars, porehes and arbors. Flowers white; very fragrant. Price, $25 \mathrm{c}$ and $35 \mathrm{c}$ each.

Jasminum (Yellow Jasmine).-A strong-growing vine with bright yellow flowers; swect scenter. Price, $25 \mathrm{c}$ and $35 \mathrm{c}$ each.

Lantana camara.-A tropical plant with bright yellow and red flowers. Suitable also for climbing. Price, 25e cach.

Lantana Sellowiana (Weeping or Trailing Lantana).-This can be grown as a climber or as a trailing shrub. Price, 25e each.

Lonicera Caprifolium (Honeysuckle).- Suitable for arbors, porehes, ete.; sweet seented. Price, $15 \mathrm{e}$ and $25 \mathrm{e}$ each.

Lonicera (Honeysuckle). $-\Lambda$ golden variegated variety. Price, $25 \mathrm{e}$ and $35 \mathrm{c}$ each.

Maidenhair Vine.-See Muchlenbeckia.

Manettia bicolor.-A delicate climber. Elegant when in flower with its red and yellow tips. Price, 150 and $25 e$ each.

Muehlenbeckia complexa (Maiclenlaair Vine, Wire Vine).-This pretty, stronggrowing elimber and trailer is very desirable for covering old stumps, trees. rock work, etc. The foliage is small, dense and graceful. Price, 25e and 35 e each.

Passion Vine.-See Taesonia.

Plumbago Capensis. - Can be trained as a bush or elimber. Flowers light skyblue, verbena-shiped, prodneed throughout the entire summer. Stands drought and water and the hrightest sunshine. Price, 50e.

Plumbago Capensis alba. - $\lambda$ white variety of above. Price, 50c each.

Potato Vine.--See Solanum jasminoides. 
Scotch Ivy.-See Hedera.

Smilax argyrea (Smilax).-A tender foliage plant of slender twining habit; stem wiry. Price, 3-inch pots, 20e each; 4-inch pots, 25e each.

Solanum jasminoides (Potato Vine).-A fast grower and valuable on account of its continual blooming period. Price, small, $20 \mathrm{c}$ each; 4 to $\tilde{\mathrm{j}}$ feet, $40 \mathrm{c}$ each.

Strawberry, Chilean.-See Fragaria Chilensis.

Streptosolen Jamesonii.-One of our best climbers, blooming the entire summer. It resembles the heliotrope in habit and foliage, but the flowers are a gorgeous yellow. Price, 4-inch pots, 3כ̌c; 5-inch pots, 50c.

Tacsonie Coccinea (Scarlet Passion Vine).-Brilliant flowers. A fast grower. Price, 50c each.

Tacsonia Mixta (Pink Passion Vine).-Suitable for fences and barns. A fast grower. Price, $25 \mathrm{c}$ and $35 \mathrm{c}$ each.

Tecoma Capensis.-Very elegant in foliage, with showy scarlet flowers. A dense grower. Price, in 6-inch pots, 50c each.

Tecoma Jasminoides.-A very handsome climber, with large pink flowers. Price, 50c each.

Tecoma radicans (Trumpet Vine).-A high shrub, climbing by its rootlets.

- Flowers yellow with scarlet limbs. Price, 50c each.

Trumpet Vine.-See Tecoma.

Vinca-Periwinkle.-Very useful for rockwork or covering trees and banks. Price, 25c per dozen; $\$ 2.00$ per hundred.

Virginia Creeper.-See Ampelopsis.

Wisteria Chinensis (Wisteria).-This plant produces a most wonderful profusion of dark purple flowers under almost any condition. Price, $\$ 1.00$ each.

Wisteria Chinensis alba.-Closely resembles W. Chinensis, excepting the flowers are white instead of blue. Price, $\$ 1.00$ each.

\section{PALIMS AND GREENHOUSE PLANTS.}

Adiantum cuneatum gracillimum (Maidenhair Fern).-A very decorating plant, elegant for its graceful fronds. Price, 4-inch pots, 35e; 5-inch pots, $50 \mathrm{c}$ each.

Adiantum cuneatum (Maidenhair Fern).-This fern is more hardy than the variety Gracillimum and has larger foliage. Price, 4-inch pots, 35c; 5-inch pots, $50 \mathrm{c}$ each.

Alocasia metalica.-This has very large oval leaves which look like polished metal shields. Price, 4 -inch pots, $25 \mathrm{c} ; 6$-inch pots, $50 \mathrm{c}$ each.

Asparagus plumosus.-Leaves bright green, gracefully arched, surpassing Maidenhair ferns in grace, fineness of texture and richness of color. The cut strands hold their shape and color for weeks. Price, $20 \mathrm{c}$ to $50 \mathrm{c}$ each.

Asparagus Sprengeri.-One of the most popular basket and decorative plants. Branches long and drooping; of easy culture. Price, 20c to $50 \mathrm{c}$ each.

Aspidistra lurida.-Excellent for the decoration of halls, stores and public places in general, since it will stand much abuse in the matter of dust, dry air and lack of water and light. Price, 35c to $50 \mathrm{c}$ each.

Aspidistra lurida variegata.-A variegated form of the above, the alternation of the green and white stripes being singularly beautiful. Price, 50c each.

Asplenium falcatum (Holly Fern).-A favorite variety for house culture. Leaves dark green and glossy; fronds gracefully arched. Price, 25c to $50 \mathrm{c}$ each.

Australian Palm.-See Corypha.

Begonia elegans.-Have several varieties of these decorative pot and garden plants. Price, $15 \mathrm{c}, 25 \mathrm{c}$ and $50 \mathrm{c}$ each.

Blechnum Brasiliense.-A showy, broad-leaved fern; suitable for parlor or hall decoration; hardy. Price, 25c and 50c each.

Cactus.-Several varieties in 4 -inch and 5-inch pots. Price, $25 \mathrm{c}$ and $35 \mathrm{c}$ each.

Chamaerops excelsa. - Suitable for sidewalks and lawns. One of our hardiest palms. Price, field grown, 1 to $1 \frac{112}{2}$ feet, $50 \mathrm{c}$ each; 2 to 3 feet tall, in tubs, $\$ 2.50$. 
Chlorophytum elatum.-A valuable and common plant for vases and pots, and freely used for hanging baskets; leaves variegated. Price, $15 \mathrm{c}, 25 \mathrm{c}$ and $35 \mathrm{c}$.

Coleus.-Very useful for decorative purposes; very showy. Price, 25c each.

Cordyline australis (Dracaena).-Broad, light green leaves; produces a tropical effect. Price, 50c each.

Cordyline indivisa (Dracaena).-The small plants make good house decorations, while the large plants are often used for street planting. Price, field-grown plants, 25e to $\$ 1.00$ each; in tubs, 50c extra.

Corypha (Australian Palm).- Slow growing, hardy and excellent for placing on porches. Price, in tubs, $\$ 2.00$.

Cyclamen.-Charming plants, with beautiful foliage and richly-colored fragrant flowers. Universal favorites for winter and spring blooming. Price, $25 \mathrm{c}$ to $35 \mathrm{c}$ each.

Cyperus alternifolius (Umbrella Plant).-Elegant for its umbrella-like foliage. Very hardy. Price, 4-inch pots, 25e; 6-inch pots, 5)(e each.

Dracaena.-See Cordyline.

Euphorbia pulcherrima (Poinsettia).-The favorite flower for Christmas decoration; nothing more gorgeous. Price, 25c to $50 \mathrm{c}$ each.

Fan Palm.- See Washingtonia.

Farfugium, or Leopard Plant.-See Senecio.

Ficus elastica (India Rubber Plant).-Very. large, smooth, leathery leaves, evergreen foliage; generally esteemed one of the finest house plants grown, the plant attaining a large size and tree-shape. Price, 75e each.

Hanging Baskets.-Filled with Asparagus Sprengerii, Boston Ferns, Pierson Ferns. Price, $\$ 1.50$ each and up.

Holly Fern.-See Asplenium.

Kentia Belmoreana (Palm).-A most delightful palm for house decorating. Price, $75 \mathrm{c}$ to $\$ 2.00$ each.

Maidenhair Fern.-See Adiantum.

Nephrolepis exaltata (Sword Fern).-Extra hardy sort, well adapted for house culture, succeeding with ordinary care. Price, $20 \mathrm{c}$ to $50 \mathrm{c}$ each.

Nephrolepis exaltata Var. Bostoniensis (Boston Fern).-A hardy, gracefully arching house fern, especially adapted for large hanging baskets. Price, $20 \mathrm{c}$ to $50 \mathrm{c}$ each.

Nephrolepis exaltata Var. Personia.-A new variety, stronger in growing fronds, broaded and with more fringes. Price, 3-inch pots, 25e; 5-inch pots, $50 \mathrm{c}$.

Nephrolepis Whitmanii.-This is one of the newest introductions to the "plume foliage" varieties, and it is certainly very fine; must be seen to be appreciated. Does beautifully in hanging baskets. Price, 75e to $\$ 1.00$ each.

Phoenix Canariensis.-Suitable for large lawns. Price, 1 foot, 35c; 2 feet, $\$ 1.00$; 3 feet, $\$ 3.00 ; 4$ feet, $\$ 5.00$; young plants, $2 \frac{1}{2}$-inch pots, $\$ 5.00$ per hundred.

Platycerium alcicorne (Stag-horn Fern).-An Australian house plant with irregularly lobed thick leaves, which are forked. Should be in every greenhouse. Price, $\$ 2.50$ each.

Poinsettia.-See Euphorbia.

Senecio Kaempferi Var. aureo-maculatus (Farfugium or Leopard Plant).Leaves round, green and spotted with yellow or white; suitable for berlding and house plants.

Stag-horn Fern.- See Platycerium alcicorne.

Sword Fern.-See Nephrolepis.

Wandering Jew.-The old-time favorite for hanging baskets and window boxes. Price, in pots, $10 \mathrm{c}$ and $20 \mathrm{c}$ each.

Washington robusta (Fan Palm).-One of California's hardiest fan palms. Very ornamental. Price, large plants, in tubs, $\$ 2.50$.

\section{BEDDING AND BORDER PLANTS.}

Achillea santolinoides.-A hardy border plant, elegant for its bluish-gray foliage. Price, 35c per dozen.

Agave Mexicana (Century Plant).-Variegated, broad foliage; suitable for tubs, beds and lawns. Price, $25 \mathrm{c}$ and $50 \mathrm{c}$ each. 
Ageratum Mexicanum.-This is a dwarf variety border plant, with blue tassels. Price, 35c per dozen.

Aloe vera.-Desert plants, with stiff, rigid leaves and bright red flowers. Price, $25 \mathrm{c}$ to $50 \mathrm{c}$.

Aloe distans.-Ornamental, variegated foliage; suitable for rockeries. Price, $25 \mathrm{c}$ each.

Aquilegia vulgaris (Columbine).-A hardy perennial, growing about 2 feet high and bearing an immense variety of colors on long, smooth stems. Price, $50 \mathrm{c}$ per dozen.

Anemone Japonica.-The most beautiful of garden flowers, and invaluable for cut flowers. Blooms from August until November. Price, 4-inch pots, $25 \mathrm{c} ; 5$-inch pots, $35 \mathrm{c}$ each.

Armeria maritima (Sea Pink). - The grass-like foliage and small pink flowers make this a very striking border plant. Price, 25e per dozen.

Asters.-We have these large, bright, summer flowers in four colors-white, red, lavender and pink. Ready February 1st. Price, 25c al dozen.

Bachelor's Buttons.-See Centaurea.

Border Pink.-See Dianthus.

Brown-eyed Susan.-See Coreopsis.

Campanula persicifolia (Hairbell).-One of the most beautiful of our native species; well adapted for border plants. Blooms all summer. Flowers white and blue. Price, 50e per dozen.

Carnations. - We offer the following varieties at $15 \mathrm{e}$ each, or $\$ 1.50$ per dozen: Eldorado, canary yellow.

Enchantress, shell pink, deepening toward center.

Flora Hill, white.

Governor Roosevelt, scarlet shaded with maroon.

Mrs. Thos. W. Lawson, deep rose-pink.

Prosperity, white suffused with pink.

Catananche caerluea.-Excellent for cut flowers and very decorative with its dry seed stems. It has handsome purple flowers, which give it a very attractive appearance. Price, 50c per dozen.

Centaurea Cyanus (Bachelor's Buttons).-A favorite blue hardy annual. Sow in spring. Price, 25c per dozen.

Century Plant.-See Agave.

Chain Fern.-See Woodwardia.

Cheiranthus Cheiri (Wall Flower).-A favorite English garden plant, suitable for borders and bedding. Price, 35e a dozen.

Chilean Strawberry.-See Fragaria Chiloensis.

Chrysanthemum Sinensis.-Our best autumn flower; extra large. We have it in four colors-yellow, bronze, white and red. Price, 20c a plant.

Cineraria cruenta.-An excellent bloomer and very striking on account of its great variety of colors. Price, in 4-inch pots, 25c each; young plants in boxes, $5 \mathrm{c}$ each, or $50 \mathrm{c}$ a dozen.

Columbine.-See Aquilegia vulgaris.

Coreopsis lanceolata.-Hardy perennial plants with large yellow flowers. The best for the garden and for cut flowers. Price, small plants, 3๊̃ per dozen; large field-grown plants, 50c per dozen.

Coreopsis tinctoria (Brown-eyed Susan).-A hardy annual, yellow with brown center. Price, 25c per dozen.

Cosmos (Mixed).-Elegant fall flowers. Price, 25c per dozen.

Cotyledon.- Succulent plants, best suited for rockeries; choice variety, silver gray in color. Price, 15e each.

Dahlia (Cactus Dahlia).- No garden should be without them; bloom a long time in summer if allowed rich soil and plenty of water; colors rich orange, primrose yellow, bronze orange and cardinal. Price, $10 \mathrm{c}$ roots.

Daisy.-Our old garden daisy, which makes'a delightful border with its mass of flowers. Propagated from selected seed. Price, 25c per dozen.

Dianthus (Border Pink).-The showy, old-fashioned border plant, with an abundance of small, sweet-scented pink flowers. Price, 35c dozen.

Dianthus barbatus (Sweet William).-This, the oldest of our garden plants; mixed colors; double flowers. Price, 50e dozen.

Digitalis purpurea (Foxglove).-This well-known plant should have a place in the garden. Price, $15 \mathrm{c}$ each; seedling, 50c per dozen. 
Echinops Bannaticus (Globe Thistle).-This perennial, 3 feet high, is highly praised for its cut flowers, which are of a deep blue and round like a ball. Price, 10c; $\$ 1.00$ per dozen.

Eupatorium riparium.-A very graceful plant, with white flowers, blooning early in the spring. Price, 25c each.

Flag Lily.--See Iris.

Foxglove.-See Digitalis purpurea.

Fragaria Chiloensis (Chilean Strawberry).-Especially graceful for walls or embankments. Price, 25c per dozen, or $\$ 2.00$ per hundred.

Gaillardia grandifiora.-Excellent for house decoration, with its large flowers of yellow with maroon centers. Price, small plants, 35̃c per dozen; large field-grown plants, 50e per dozen.

Geraniums.-Excellent for window boxes, border plants and hedges; double or single flowers, variegated foliage, and bright or rlark red in rolor. Price, $10 \mathrm{c}$ and $20 \mathrm{c}$ each; $\$ 1.00$ and $\$ 2.00$ per dozen.

Geum coccineum.-This makes a fine hardy border and is also elegant for rock work. Flowers bright red. Price, 35c per dozen.

Globe Thistle.-See Echinops Bannaticus.

Golden Feather.-See Pyrethrum.

Golden Glow.-See Rudbeckia laciniata.

Golden Rod.-See Solidago Canadensis.

Hairbell.-See Campanula.

Iris Germanica (Flag Lily).-Very hardy bedding plants, and may also be - used for border. We have this in three colors-white, blue and variegated. Price, 5c a root.

Iris orientalis.-One of the largest of the Irises; grows in almost any situation. Flowers white with yellow centers. Price, $10 \mathrm{c}$ root; $\$ 1.00$ a dozen.

Ice Plant.-See Mesembryanthemum.

Lobelia Erinus.-Remarkable for their profusion of blue flowers. Good for borders and for hanging baskets. Price, 35c per dozen.

Matthiola Sinuata (Ten-weeks Stocks).-We have these strong bloomers in various colors-pink, blue, lavender, white, extra double. Price, 35c per dozen.

Mesembryanthemum roseum (Ice Plant).-The best for banks and borders. Price, 5c each, or 50c per dozen.

Mignonette.-See Roseda odorata.

Oriental Poppy.--See Papaver orientale.

Oryzopsis Miliacea.-Ornamental grass. Best for vases and with cut flowers. It has long stems of two to three feet, droops gracefully and does not drop its seeds. It is a perennial and will keep a long time. Price, 5c; $50 \mathrm{c}$ per dozen.

Pansies.-Extra large strain from best imported German seeds. Price, strong plants, 35c per dozen.

Papaver orientale (Oriental Poppy).-One of the most robust and largest of poppies. Flowers deep red, six inches in diameter. Price, $15 \mathrm{c}$ each.

Pelargonium (Lady Washington).- A garden plant offering an exquisite combination of colors-dark, deep rich crimson, maroon, double white. Price, $25 \mathrm{c}$ each, in pots.

Pentstemon gloxinioides.-A profuse bloomer, very satisfactory for a liardy border. We have it in two colors. Price, 4 -inch pots, $25 \mathrm{c}$ each.

Petunia (Double).-A showy, fragrant flower in different colors. Price, 15e and $25 \mathrm{c}$.

Polystichum aculeatum (Sword Fern).-A hardy dwarf fern, good for shady corners. Price, strong plants, 35c each.

Primula, Primrose (Double Pink).-Hardy, blooming all winter. Best for a shady situation. Price, 50e per dozen.

Primula, Primrose (Yellow). - An old English variety that is always desirable for borders. Price, 50e per dozen.

Primula Sinensis, or Chinese Primrose-Greenhouse or pot plants, bearing large single or double blossoms in bright colors, as well as soft tints. Price, 20c each, in 4-inch pots.

Pyrethrum parthenifolium aureum (Golden Feather).- Easily grown for borders. Price, 25e per dozen.

Reseda odorata (Mignotte).-A favorite swert-seented annual. Sow in spring. Price, 25c per dozen. 
Rudbeckia laciniata (Golden Glow).-A striking plant with its tall panicles of golden double flowering heads. Price, 25c a clump.

Sage.-See Salvia.

Salvia.-An ornamental variegated sage. Price, 25e each.

Salvia officinalis (Sage).-May be used as a spice and also as a border plant. Price, 5e per root.

Saxifraga crassifolia.-Its green foliage is very ornamental in eontrast with its pink flowers. It grows in shady places and blooms all winter. Priee, 5-inch pots, $35 \mathrm{c}$ each.

Sea Lavender.-See Statice limoniun.

Sea Pink.-See Armeria maritima.

Sedum Siaboldii Var. variegatum.-Desirable for borders and also for house plants. Price, 3 -inch pots, $15 \mathrm{c}$; 4 -inch pots, $25 \mathrm{c}$ each.

Sempervivum globiferum (Hen-and-Chickens).-A succulent plant, good for borders on dry places. Lives without eare. Price, 35e per dozen.

Sempervivum tabulaeforme.-A giant variety of Hen-and-Chickens. Ornamental for tubs or rockeries. Price, $25 \mathrm{c}$ each.

Senecio grandiflorus.-Ornamental in foliage, and bears a mass of flowers. Price, $35 \mathrm{c}$ each.

Solidago Canadensis (Golden Rod).-One of the glories of autumn. Its yellow flowers on long spikes will light up a gloomy corner. Price, strong plants, $25 \mathrm{c}$ each.

Statice limonium (Sea Lavender).-Very showy with its bright green leaves and large heads of blue flowers, which will last for weeks after cutting. Price, 25c each.

Stokesia Cyanea (Stoke's Aster).-A very choice and rare perennial with blue flowers two to three inches in diameter. Price, $15 \mathrm{e} ; \$ 1.50$ per dozen.

Stocks.-See Matthiola sinuata.

Sweet William.-See Dianthus barbatus.

Sword Fern.-See Polystichum.

Telanthera.-Much used for borders because of their low, compact growth; stand clipping well; colors red and dark variegated. Price, 35c a dozen.

Thyme.-See Thymus.

Thymus vulgaris (Common Thyme).-The best border plant for the garden, with its striking dark-green foliage. This herb is also used for seasoning. Price, $5 \mathrm{c}$ each, or $50 \mathrm{c}$ per dozen.

Verbena.-This is so well known that it needs no comment. Very ornamental. We have it in all colors. Price, 3 -inch pots, 15e each.

Violet, California.-Best winter blooming border violet; large, blue, long stemmed and sweet scented. Price, 25e per dozen.

Violet (Prince of Wales).-A vigorous growing variety with large stems, large flowers and large foliage. Best of all. Price, 25c per dozen.

Wall Flowers.-See Cheiranthus cheiri.

Woodwardia radicans (Chain Fern).-The strongest fern in California, growing about two to four feet tall. Very decorative, either in the garden or the house. Price, field grown, 25e each; strong plants in pots, 35e each.

\section{VEGETABLE PLANTS.}

Young Vegetable Plants will be ready February 1st.

Cabbage.-Price, $15 \mathrm{c}$ per dozen.

Cauliflower.-Price, $15 \mathrm{c}$ per dozen.

Kale.-Price, $15 \mathrm{c}$ per dozen.

Tomatoes.-Price, 25c per dozen.

\section{BULBS.}

Agapanthus umbellatus (Blue African Lily).-An ornamental plant with thick, fleshy leaves. Price, 25c each.

Amaryllis Belladonna (commonly known as Resurrection Lily).-Flowers pink and fragrant. Price, large bulbs, $15 \mathrm{c}$ each; small bulbs, $\$ 1.00$ per dozen. 
Blue African Lily.-See Agapanthus.

Calla Lily.--See Richardia Africana.

Chinese Sacred Lily.-See Narcissus.

Crocus.-A bright and early spring flower. Price, 10e per dozen.

Daffodils.-See Narcissus.

Freesia.-Popular bulbous plants which may be grown in the home windows or in the garden. Price, $15 \mathrm{c}$ per dozen.

Galanthus (Snowdrops).-Among the dainties of our common hardy springblooming bulbs; flowers pendulous, white with a heart-shaped seal of green. Price, 25c per dozen.

Gladiolus (The Bride).-Pure white, very handsome and excellent for decorating. Price, 25e per dozen.

Gladiolus (Sword Lily).-Mixed in color; remarkable for habit and beauty of color. They may be had in pure white, scarlet, rose, purple and yellow. Price, 25c a dozen.

Hemerocallis flava (Lemon Lily).-A very fragrant, clear yellow flower, borne in clusters on tall stems. Price, 25c plant.

Hyacinth.-Single flowers in red, white, blue or pink. Price, 75e per dozen.

Jacobean Lily.-See Sprekelia.

Jonquils.-See Narcissus Tazetta.

Lemon Lily.-See Hemerocallis.

Narcissus major (Daffodils).-Early bloomers; flowers trumpet shaped, white and yellow. Price, 35c per dozen.

Narcissus poeticus (Single).-A very ornamental long-stemmed white flower. A long bloomer. Price, 25e per dozen.

Narcissus Tazetta (Jonquils).-Single white, early bloomer, very fragrant. Price, 25c per dozen.

Narcissus Tazetta (Jonquil).-Single yellow, very fragrant, early bloomer. Price, 25c per dozen.

Narcissus Tazetta Var. orientalis (Chinese Sacred Lily).- White flower with yellow cup; very fragrant. Grows in water or in soil. Price, 10e each; $75 \mathrm{c}$ per dozen.

Ranunculus Asiaticus.-Highly-bred Persian buttercups of various colors; resemble the Shirley Poppy at a distance. Price, 20c per dozen.

Resurrection Lily.-See Amaryllis.

Richardia Africana (Calla Lily).-Price, 25e per dozen.

Scilla Peruviana.-One of the finest bulbs grown, with large blue flowers eight to ten inches in diameter. Price, $25 \mathrm{c}$ each.

Snowdrops, California Giants.-See Galanthus.

Sprekelia formosissima (Jacobean Lily).-Strap-shaped leaves and large dark crimson flowers. Price, 25e each; $\$ 2.50$ per dozen.

Sword Lily.-See Gladiolus.

Tritonia crocosmaeflora.-This hybrid is very showy with its slender stems. Color, bright orange. Price, $15 \mathrm{c}$ per dozen.

Tulips (Darwin).-The largest of the late flowering types, with long stems, and a variety of colors, golden yellow, pure white, common searlet with violet black center mixed. Price, 35c per dozen.

Watsonia Ardernei (White Watsonia).-Pure white wax-like flowers. Prien, $50 \mathrm{e}$ per dozen.

\section{SEEDS.}

LAWN SEEDS.

Pound.

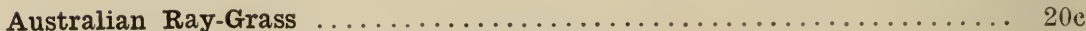

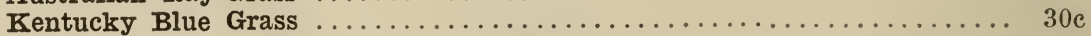

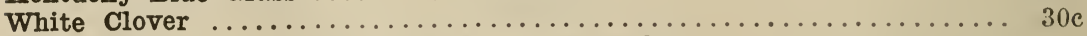

Flower Seeds.-In variety; $5 e$ and $10 \mathrm{e}$ per packet.

Vegetable Seeds.-Large collection; 5e and 10e per packet. Put up by a reliable firm. 


\section{N D E X.}

\begin{tabular}{|c|c|}
\hline \\
\hline & Abutilon ................................ 8 8 Camphora ............................. 9 \\
\hline \\
\hline & \\
\hline 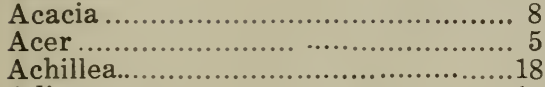 & Caryopteris ... \\
\hline \multirow{2}{*}{$\begin{array}{l}\text { Adiantum } \\
\text { Agapanthus } \ldots \ldots \ldots \ldots \ldots \ldots \ldots \ldots \ldots \ldots \ldots \ldots \ldots \ldots \ldots \ldots \ldots \ldots \ldots \ldots \ldots \ldots \ldots \ldots \ldots \ldots \ldots \ldots \ldots\end{array}$} & Cassia. \\
\hline & \\
\hline Agave ..................................... 18 & Catananche \\
\hline \multirow{2}{*}{ 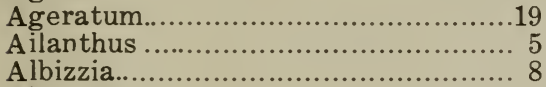 } & 21 \\
\hline & $\begin{array}{r}9 \\
9\end{array}$ \\
\hline \multirow{2}{*}{ 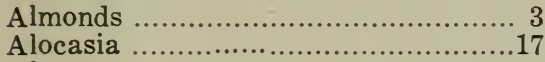 } & irea \\
\hline & .19 \\
\hline \multirow{2}{*}{ 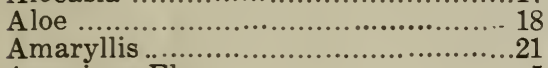 } & \\
\hline & Cestrum. \\
\hline \multirow{2}{*}{ 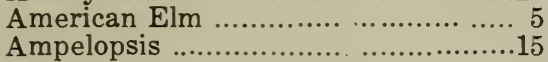 } & Chain Fern. \\
\hline & Cha \\
\hline \multirow{2}{*}{ 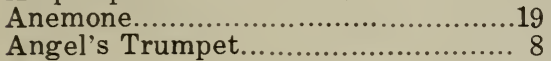 } & \\
\hline & Chei \\
\hline & \\
\hline .3 & Chil \\
\hline & berry \\
\hline & Chin \\
\hline & Ch \\
\hline & Cho \\
\hline & \\
\hline & Cin \\
\hline & \\
\hline & \\
\hline & \\
\hline & C \\
\hline & \\
\hline & \\
\hline .22 & rry \\
\hline & \\
\hline & \\
\hline Buttons. & C \\
\hline & .19 \\
\hline 18 & \\
\hline & \\
\hline & \\
\hline & \\
\hline & C \\
\hline & \\
\hline 6 & owered Eucalyptus.. \\
\hline & 22 \\
\hline & \\
\hline .22 & \\
\hline & \\
\hline & \\
\hline & \\
\hline & \\
\hline .16 & \\
\hline & \\
\hline .8 & \\
\hline & bs. . \\
\hline & $\mathrm{D}$ \\
\hline & \\
\hline & \\
\hline & \\
\hline & \\
\hline & $\mathrm{D}$ \\
\hline & \\
\hline .19 & y Mille \\
\hline & Echinops \\
\hline
\end{tabular}




\section{INDEX.-Continued.}

English Ivy

Erica

Escallonia

Eucalyptus.

Eugenia

Euonymus.

Eupatorium

Euphorbia

European Holly

Evergreen Trees and Shrubs.

Exochorda.

Fagus.

Fan Palm.

Farfugium

Ficus.

Field Oak

Figs.

Flag Lily

Flower Seeds.

Flowering Maple

Forsythia

Foxglove.

Fragaria

Freesia .................................22

Fuchsia

Gaillardia

$10-16$

Gaillardia

Genista

Geranium

German Broom

German Ivy

Geum

Giant Reed

Ginkgo

Gladiolus

Globe Thistle

Gnaphalium

Gold Flower

Golden Arborvitae

Golden Bell

Golden Chain

Golden Dew Drop

Golden Dust Tree

Golden Feather.

Golden Glow

Golden Rod

Golden Wattle

Gooseberries

Grapes

Grevillea

Gum Tree

Hairbell

Hanging Baskets

Hawthorn

Heath

Hedera

Heliotropium

Hemerocallis

Himalaya Blackberry

Holly

Holly Fern

Honeysuckle

Hops.

Horseradish

House Plants

Humulus

Hyacinth
16 Hydrangea.

Hypericum.................................... 6

Ice Plant.................................... 20

Ilex .............................................. 10

Iochroma ..............................6-10

Irish Juniper................................. 10

Iris ..........................................20

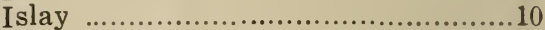

Ivy Geranium ......................................16

Jacobean Lily..............................22

Jacobinia .................................10

Japanese Quince ........................ 6

Japanese Snowball ....................... 6

Jasminum .................................... 16

Jonquils.........................................22

Judas Tree..................................... 6

Juniper .................................................. 10

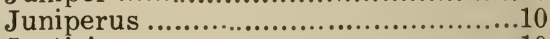

Justicia .......................................... 10

Kale ............................................... 21

Kangaroo Thorn...........................10

Kentia ...................................... 18

Kentucky Blue-grass.....................22

Kerria ........................................ 7

Laburnum ......................................... 7

Lantana ........................................ 16

Large-leaved Maple....................... 7

Laurestina ....................................... 10

Lavender ....................................... 10

Lawn Seeds..................................... 22

Lawson Cypress................................ 10

Lemons .......................................... 3

Lemon Lily .........................................22

Lemon Verbena................................... 7

Lobelia ..........................................20

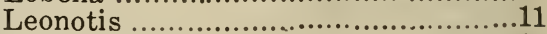

Leptospermum ............................11

Ligustrum .................................11

Lilac …......................................... 7

Linden ...................................... 7

Liion's Ear........................................17

Loppia ....................................... 7

Lobelia ............................................ 20

Loganberries................................... 4

Lonicera ........................................... 16

Magnolia............................................ 11

Maidenhair Fern ........................... 18

Maidenhə.ir Tree ............................... 7

Maidenhair Vine ...........................16

Malvastrum ...................................11

Manna Gum ...................................11

Manettia .. .................................16

Marguerite ........................................ 11

Matilija Poppy.............................11

Matthiola ....................................20

Maytenus ........................................... 11

Mesembryanthemum .................... 20

Mignonette .................................... 20

Mock Orange................................... 7

Monkey Puzzle.............................11

Monterey Cypress................................ 11

Muehlenbeckia ...........................11-16

Myrtus........................................ 11

Narcissus .........................................22

Nephrolepis .............................. 18

New Zealand Flax .............................11

Nerium ..............................................11

Norfolk Island Pine......................11 


\section{INDEX. - Continued.}

\begin{tabular}{|c|c|}
\hline & mpervivium. \\
\hline ranges & $12-18-21$ \\
\hline riental Pop & equoia \\
\hline zopsis.. & Silk Oak . \\
\hline Ims and Green & ilver Maple \\
\hline nsies ............... & Smilax ......... \\
\hline paver.. & milax 'Tree \\
\hline ssion Vine & Snowball...... \\
\hline ches $\ldots$ & berry. \\
\hline B Bush. & rops. \\
\hline $\operatorname{ars} \ldots \ldots \ldots$ & olanum \\
\hline largonium & Solidago ............ \\
\hline tstemon & Spanish Broom. \\
\hline eer $\mathrm{T}$ & $\begin{array}{l}\text { Spartium ........ } \\
\text { Sprekelia ....... }\end{array}$ \\
\hline tunia. & Stag-horn Fern \\
\hline iladelphus & 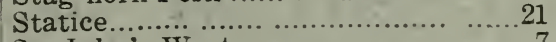 \\
\hline enix & St. John's Wort. \\
\hline $\mathrm{im}$ & s......... \\
\hline hys & vberry, C̈h \\
\hline $\begin{array}{l}\text { Pittosporum } \\
\text { Plums.. }\end{array}$ & $\begin{array}{l}\text { Strawberry, } \\
\text { Strawberries.... }\end{array}$ \\
\hline $\begin{array}{l}\text { Plums............. } \\
\text { Plumbago ... }\end{array}$ & Streptosolen .. \\
\hline im & Sugar Maple \\
\hline nset & Swa \\
\hline $\mathrm{s} \mathrm{N}$ & Sweet William \\
\hline$\ldots \ldots 11$ & Sword Fern. \\
\hline lus $\ldots . . .$. & d Lily ........ W \\
\hline $\begin{array}{l}\text { Vine } \\
a \ldots \ldots . . .\end{array}$ & Symphorocarpus \\
\hline $\begin{array}{l}\text { Primula ......... } \\
\text { Privet .......... }\end{array}$ & r.............. \\
\hline & l'ac \\
\hline-11 & Tagetes. \\
\hline -leaved & 17 \\
\hline ved Plu & $\begin{array}{l}\text { Tecoma ...... } \\
\text { Telanthera }\end{array}$ \\
\hline $\begin{array}{l}20 \\
11\end{array}$ & $\begin{array}{l}\text { Telanthera ..... } \\
\text { Thuya ............. }\end{array}$ \\
\hline & e ........................ \\
\hline $\begin{array}{r}3 \\
.22\end{array}$ & 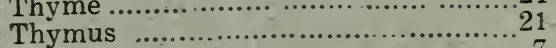 \\
\hline es. & (................... \\
\hline & \\
\hline & of Heaven.. \\
\hline ion Lily & pet Yine..... \\
\hline & et Vine.. \\
\hline & Uln \\
\hline 12 & $\cdots \cdots$ \\
\hline 12 & 21 \\
\hline & $\cdots \cdots$. \\
\hline arius ........... & ….... \\
\hline 21 & 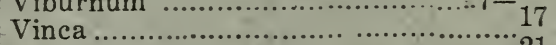 \\
\hline 21 & Violet. \\
\hline & Virginia Creeper......... \\
\hline 21 & \\
\hline & \\
\hline t Thorn & ring Jew \\
\hline .12 & ingtonia \\
\hline & Wa \\
\hline & 17 \\
\hline Lavender & g Willow.. \\
\hline Pink... & $\begin{array}{l}\text { Clover } \\
\text { Poplar }\end{array}$ \\
\hline eas .. & Woodwardia. \\
\hline
\end{tabular}


